\title{
Local Language Maintenance through Folklore Translation in Historical Tourism
}

\author{
Ayu Ida Savitri \\ \{ayuidasavitri@lecturer.undip.ac.id\} \\ English Literature Undergraduate Study Program, Linguistics Department, Diponegoro University, \\ Jl. Prof. Soedarto, S.H. Tembalang, Semarang.
}

\begin{abstract}
Language is one of human civilization evidences reflecting the culture of its speakers. When it is dead due to the inexistence of its speakers or their language shift into another one, the culture is also endangered to be extinct. Language maintenance is needed to preserve it along with the culture. One of the ways to keep them is by using it in tourism business where it can be introduced and preserved. This research describes Cambodian local language maintenance through the translation on the information board and the live-recorded information played on the recording tool in a historical tourism site, The Killing Fields. The results shows how the information board and the live-recorded information were beneficial in introducing and preserving the local language through the written and oral translation of the original orthographic and sound of the language for tourists who are interedted in cultural-historical tourism site.
\end{abstract}

Keywords: translation, Cambodian local language, language maintenance, tourism.

\section{Introduction}

Culture can be defined as the characteristics and knowledge of a certain group of people, covering language, religion, cuisine, social habits, music and arts [1]. Language, both spoken and written, as part of culture becomes an important one as it tells the culture of the language users embedded in religion, cuisine, social habits, music and arts. Without language, the culture cannot be passed down to the next generation. When the language speakers were gone leaving nobody who can either speak or understand the language and the language is no longer used, the language is dead. To keep the language alive, the speakers along with the whole community in a particular area who do not speak the language must support the use of the language and pass it down to the next generation both in conventional and modern ways to keep up to date with the latest technology. For example, the use of the language in modern art, entertainment business, or advanced technology.

One of many ways to maintain language, particularly the local one, is by using or integrating it in tourism business attracting international tourists who concern on cultural or historical tourism. On February 2019, along with the $15^{\text {th }}$ Camtesol Event at The Institute of Technology of Cambodia, the writer visited one of many cultural and historical tourism sites in Phnom Penh, Cambodia. which utilized both conventional and modern ways of preserving Cambodian local language by using and translating the language written in the information board and to be listen from an audio tool in its cultural-historical tourism site visited by many international tourists, named The Killing Fields. 
This tourism site offers visitors an audio tour, where they take a walk into 19 locations in Figure 1 [1] containing 19 Information in Figure 2. [2] related to the tragedy by taking an audio tool in Figure 3. [3] resembling a mobile phone to listen to certain explanation describing what happened in certain location they visited. The explanation were carried out in many languages visitors can choose based on their nationality or language choice at the entrance, like English, French, Chinese, an so on. Visitors can understand well about the tragedy without any help from the tour guide. However, some of the explanations were given in Cambodian local language along with its translation into the languages choices. This research shows how Cambodian local language (most of Cambodian use it along with French as their official language) is used to tell visitors about the history along with the folklore of the tragedy. The research exposes the benefit of the local language use to support Cambodian tourism business and to preserve Cambodian local language as part of Cambodian identity and culture.

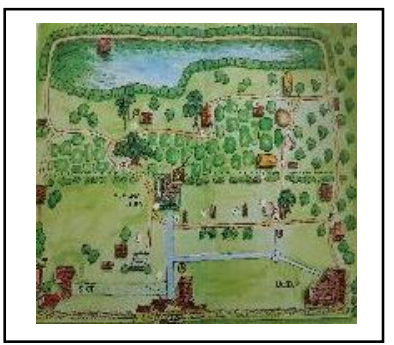

Figure 1. The 19 Locations

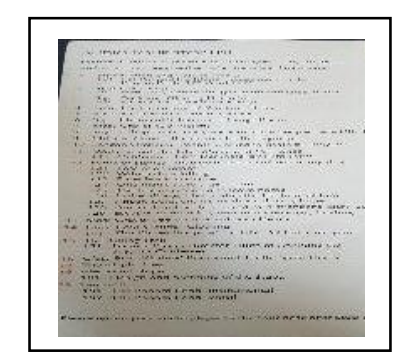

Figure 2. The 19 Information

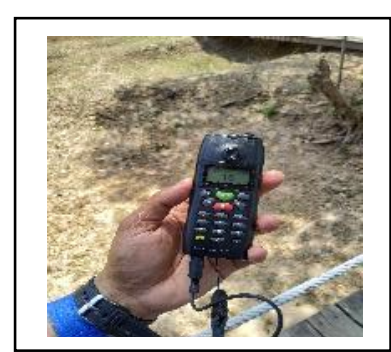

Figure 3. The Audio Tool

\section{Method}

This desrciptive-qualitative research shows how a local language is used to tell people about the history along with the folklore aimed at supporting cultural-historical tourism and maintaining the language as part of the people identity and culture. The object of the research as the data source is selected using Purposive Sampling Method [2] to chose the most famous cultural-historical tourism site in a city using the local language. The data were collected from the information board and audio tool as the primary data source using Documentation and Note Taking Methods [3]. The stories were obtained by using Identification and Interpretation Methods [4] to get the most comprehensive sample and the meaning of the data [5].

\section{Result and Discussion}

The Killing Fields or The Choeung Ek Genocidal Center is a cultural-historical tourism site located in Choeung Ek Village, approximately $15 \mathrm{~km}$ southeast of Phnom Penh, the capital city of Cambodia. It is a memorial site of a mass killing tragedy of millions of middle class Kampuchean by Pol Pot regime who led Democratic Kampuchea (now Cambodia) from 1975 to 1979 . At that time, the authorized regime Khmer Rouge cruely imprisoned, brutally killed and inhumanly buried them in mass graves scattered around Cambodia including Choeung Ek Village known as the biggest mass grave with over 300 killing fields that made it as an official tourism site. 
After the regime has been put down and Pol Pot was brought into international court, the victims' remaining corpses skeletons were excavated and thoroughly examined by Cambodian new authority -supported by the international world- to identify the victims' identity (age and gender) and to investigate the ways Khmer Rouge soldiers violently kill them. Some of the victims' remains were taken and buried by their families after being identified, but some of it, particularly their skulls were placed in a giant glass storage in Figure 4 [4] inside the Memorial Stupa in Figure 5. [5]) to remind us of the tragedy and to keep everybody alert of the rising of similar regime in the future.

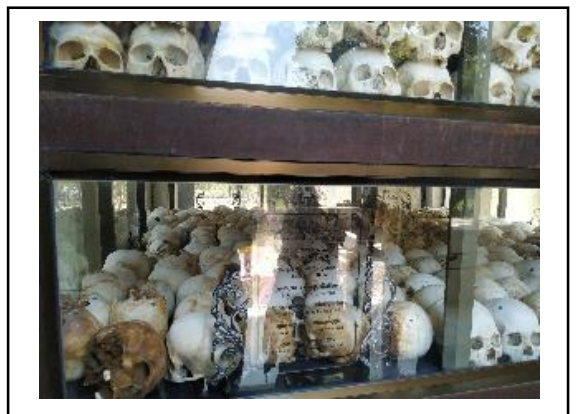

Figure 4. The Giant Glass Storage

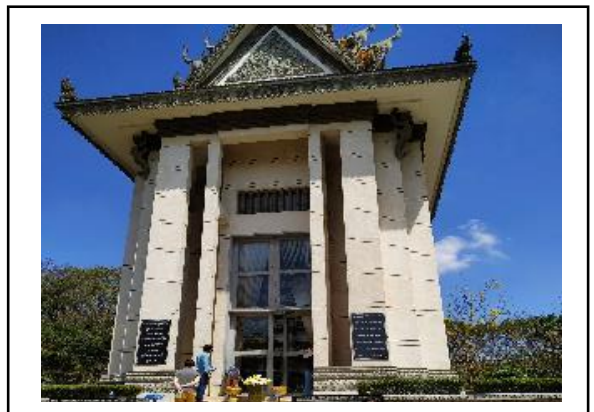

Figure 5. The Memorial Stupa

The tour covers 19 locations with 19 information or explanation in the form of a narration started from the time when Pol Pot along with his Khmer Rouge regime march into Phnom Penh City in April $17^{\text {th }} 1975$ and ended with a farewell to the visitors where the audio played a very touching instrumental and vocal entitled "Oh Phnom Penh" after the visitors left the Memorial Stupa. The tour can take as many time as the visitors want.

As it is cultural-historical tourism site to honor the victims of the tragedy, visitors were asked to dress modestly, speak quietly and not smoke around the site. To get into the Memorial Stupa, visitors were asked to take off their shoes and hat. After getting the ticket, visitors were asked to take an audio tool and choose the language they want to listen based on their nationality or simply language choice like Indonesian who choose English as Indonesian language is not available. The tour started from the entrance in front of the Memorial Stupa where visitors were asked to turn right to go to the first location and ended on the left side of the Memorial Stupa as the 18th location where they were invited to come in and see themselves some of the victims' bones along with particular signs showing its classification of age, gender and ways of killing.

The victims were taken randomly from infant to senior citizen of all sex including pregnant women. It is said that the regime were also rape the women at any age as there is a particular grave full of women without any clothes in Figure 6. [6]. The victims were taken with trucks with different reasons such as being taken for a better future, seeing their family or relatives who were taken before or simply taken without knowing why or where they were taken into. They were arrived in a place where many people were kept in a dark an gloomy detention far away from the people waiting for their turn to be executed. The regime also built an office for their soldiers who worked as the executioners, a chemical substance storage room and a killing tools storage room. The victims were killed by shooting/hitting their heads with particular killing tool, slaying their head off , poisoning them or simply beating and burrying them in the ground. When the time for the execution came usually at night, the regime played 
a traditional Cambodian song outloud to hide the sound of the victims' moan, cry, or scream for mercy during the execution.

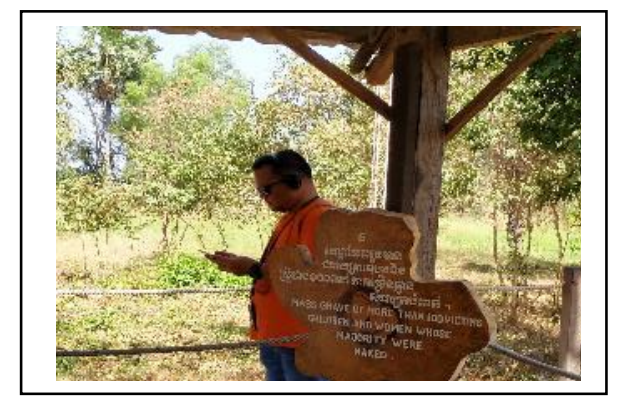

Figure 6. Grave of women without clothes

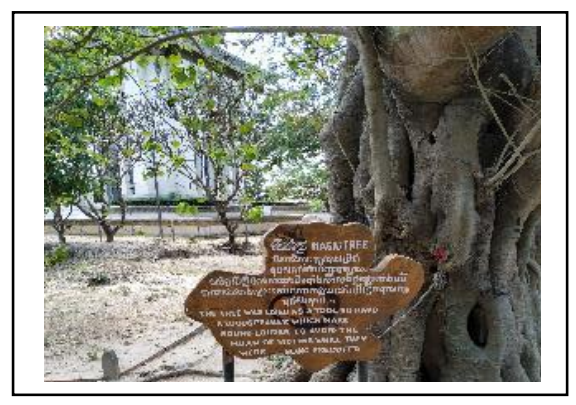

Figure 7. The Magic Tree

Far inside, there is an abandoned lake which is said to be the graveyard of the victims who were thrown away into the dark and gloomy lake full of wild and dead plants around and inside the lake. The authority decided to let them buried peacefully there since it is more difficult to take and then examine them. The traditional Cambodian song was played when visitors arrived on the lake to let them rest after a long tour before turning back and walking into the next location.

There is also the Magic Tree in Figure 7. [7\} which was used to hang the loudspeaker playing the Traditional Cambodian songs outloud to cover the victims' scream to hide their killing activities. When the victims' corpses were found and planned to be excavated to be identified and examined, it was said that blood, skeletons, teeth and clothes were emerging from the ground containing thousands of victims with the smell of dead body spreading around the site.

Related to the use of Cambodian local language, this site use the language to give information on the information board using the original Cambodian letters resembling Javanese, Indian or Thai letters along with its translation in English. Unfortunately, it is not equipped with phonetic symbols so that visitors do not understand how to read or pronounce it well. Nevertheless, visitors still interested in the language as it serves as Cambodian people identity which is interested to be studied by visitors. The example of the language use in the information board can be seen in the sign board directing visitors toa certain location in Figure 8.[8], in the information boards in the graves in Figure 6. [6] and that of next to the glass box in Figure 9. [9], and in the glass board displaying the regime activities in Figure 10. [10].
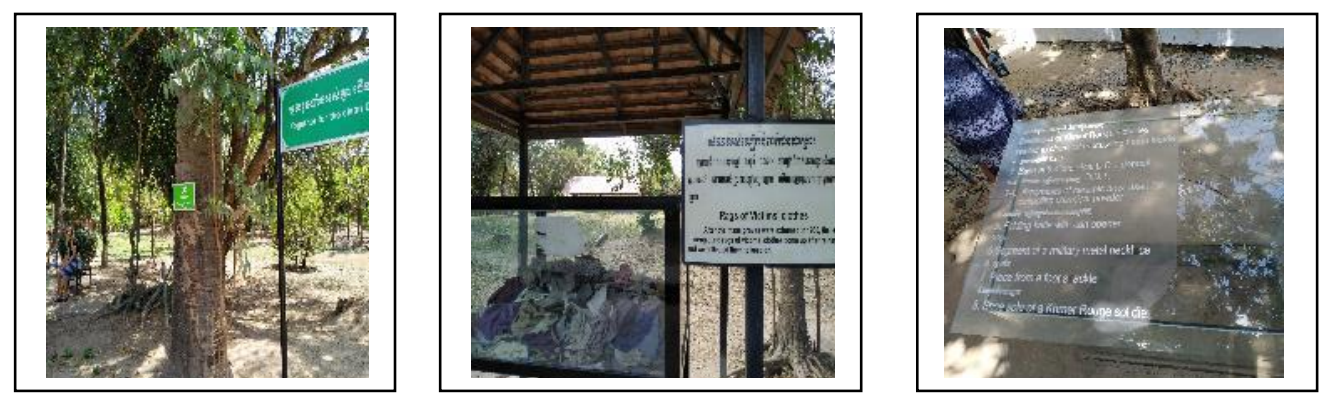
Some stories in the audio tool were also told in Cambodian local language along with its translation in any languages the visitors chosen. The example of the language use in the audio tools is the nine survivors' stories, the former prison director duch of Choeung Ek confession and the traditional Cambodian songs.

The use of the Cambodian local language on the information board and the audio tool, although not many visitors understand how to pronounce the word, read the sentence or understad the meaning, is beneficial to expose the local language into the visitors as one of tourism attraction, particularly in a cultural-historical tourism. It is also serves as one of the ways of maintaining the local language beside using it as a medium of delivering the tourism information by the local tour guides together with the foreign languages the tourists need. Therefore, the local language will be maintained and can be taught to visitors who are interested in learning the langguage.

\section{Conclusions}

From the previous section, it can be concluded that Cambodia has an effort to maintain its local language through tourism business by using it along with the foreign languages needed by the foreign visitors. The language is used both written and oral in the information board using the Cambodian language letters along with its translation in English and in the audio tools using oral (direct) Cambodian narration together with its translation in any languages the visitors chosen when taking the audio tool. It means that the way of maintaining the language is quiet comprehensive covering the orthographic, the written sentence and the direct speech. Further study can be done by taking different object of research in different countries to see how they maintain their local language as part of their identity and culture.

\section{Acknowledgements}

This acknowledgement goes to Setyo Cahyono Prasiyanto and Ade Septemuryantoro from the Faculty of Cultural Study, Dian Nuswantoro University who assisted the writer in doing this study and gave valuable contribution toward this study.

\section{References}

[1]. K.A. Zimmermann, July 12201712 p.m. E.T. Contributor, Live Science. What is Culture? <https://www.livescience.com/21478-what-is-culture-definition-of-culture.html > 15 Juli 2019

[2]. Sugiyono, Metode Penelitian Kualitatif dan R\&D, CV Alfabeta, Bandung (2010)

[3]. Sudaryanto, Metode dan Aneka Teknik Analisis Bahasa. (Pengantar Penelitian Wacana Kebudayaan secara Linguistik), Duta Wacana, Yogyakarta (1993)

[4]. A. Dundes, Editor. The Study of Folklore. Upper Saddle River, Prentice Hall, New Jersey (1965)

[5]. S.J. Bronner, Editor. The Meaning of Folklore: The Analytical Essays of Alan Dundes. Logan, Utah: Utah State University Press. (2007)

[6]. 40 Fakta Menarik tentang Kamboja <https://semestafakta.wordpress.com/2015/02/07/40-faktamenarik-tentang-kamboja/ 24 Juli 2019 
[7]. RR Laeny Sulistyawati, Jumat 15 April 2016 05.30 WIB. Sejarah Hari Ini:

Mantan

Diktator yang 'Bunuh' 1,7 Juta Warga Kamboja Tutup Usia. <https://www.republika.co.id/berita/internasional/selarung-waktu/16/04/15/o5mz09377-sejarahhari-ini-mantan-diktator-yang-bunuh-17-juta-warga-kamboja-tutup-usia>24 Juli 2019. 